Understanding the Quality of Out-of-Class English Learning

\begin{abstract}
Out-of-class learning constitutes an important context for human development, and active engagement in out-of-class activities is associated with successful language development. However, not all out-of-class experiences are equally beneficial to learning, and it is of paramount importance to understand what quality out-of-class English language learning entails. This study surveyed eighty-seven middle school EFL students on their out-of-class English language learning in order to identify the characteristics of the experiences that are associated with good learning outcomes. The study found that out-of-class learning composed of diversified constituents that met the varied needs in language learning and complemented in-class learning by striking a balance between focus on meaning and focus on form were positively associated with good English grades, English language learning efficacy and enjoyment. It also found that parents and teachers were significant sources of influence on the quality of students' out-of-class learning. Keywords: out-of-class learning; informal learning; language learning ecology
\end{abstract}

Learning involves the accumulation of experiences across a variety of formal and informal settings with unique strengths that complement each other (Colley, Hodkinson \& Malcolm, 2003; National Research Council, 2009). In-class and out-of-class learning environments form "a complex web of synchronic as well as chronological learning opportunities” (Bäumer et al., 2011, p. 92). Thus, out-of-class learning constitutes an important context of human development and is indispensable for effective learning (Hall, 2009). In particular, out-of-class learning has been shown to be positively associated with language gains (Inozu et al, 2010; Larsson, 2012; Richards, 2009; Sundqvist, 2011), and successful language learners have often been 
found to seek out and utilize various out-of-class opportunities for learning (Benson et al., 2003; Borrero \& Yeh, 2010). Therefore, supporting language learners to construct quality out-of-class learning experiences is important (Blyth \& LaCroix-Dalluhn, 2011; Stickler \& Emke, 2011). This issue is particularly critical in instructional contexts where in-class instruction focuses predominantly on one aspect of language learning (e.g., on language forms). This is usually the case with English language teaching in China, particularly secondary schools, which is often reported as being heavily exam- and grammar-oriented (Butler, 2011; Pan \& Block, 2011). ELT in China has been described as being dominated by the Grammatical Translation and Audio-Lingual methods (Wilhelm \& Pei, 2008), with grammar exercises, translation and filling in worksheets being the most frequent activities in English classes (Song, 2013). Butler (2011) highlighted that in such instructional contexts, it is essential to develop "communities of learning outside the classroom” (p. 50) and engage students in out-of-class learning to enrich their overall learning experience. However, to support language learners in constructing beneficial out-of-class learning experiences, we need first and foremost to understand what quality out-of-class language learning experiences entail (Benson, 2011). This study intends to shed light on this less-charted terrain (Benson, 2007; Benson \& Reinders, 2011) and focuses on unraveling the relationships between the characteristics of out-of-class learning and language learning outcomes.

\section{RESEARCH BACKGROUND}

Language learning is inextricably linked to the various social actions and interactions in the multiple contexts in which learners engage (Borrero \& Yeh, 2010; Menezes, 2011). Language learners need to capitalize on the particular strengths and affordances of different learning contexts to meet their cognitive, social, affective, and identity needs in language learning (Blyth \& LaCroix-Dalluhn, 2011; Stickler \& 
Emke, 2011). As Richards (2009) rightly pointed out, "it has taken us a while to realize that while good teaching is no less important than ever, today's learners are not as dependent on classroom-based learning and teaching as they used to be” (p.10). In effect, language learners of all ages have been found to utilize various structured or unstructured social, discursive and material resources to support their language learning beyond formal language learning contexts (Lai, 2013; Gao, 2010).

Research has shown that out-of-class learning plays a significant role in language learning (Pearson, 2004; Inozu et al 2010). Richards (2009) identified that young people in northern European countries, such as Sweden and Finland, demonstrated greater English language achievement than their counterparts in countries like Spain, Italy, Korea and Japan. He attributed this difference to the frequent use of undubbed English media (e.g., TV programs and movies) among the former and the lack of exposure to authentic English outside their English classrooms among the latter. Similarly, Nunan (1991) pointed out that learners who achieve high levels of English proficiency often attribute their success to out-of-class learning. Sundqvist (2011) examined the relationship between the amount of time Swedish English language learners spent on out-of-class learning and their oral proficiency”, and found that out-of-class learning correlated significantly with oral proficiency (0.31) and vocabulary size (0.36). The amount of out-of-class learning was also found to correlate positively with self-efficacy in English. Larsson (2012) examined the impact of out-of-school English language activities on students' scores in the National Test of English in Sweden and found that students who were not involved in out-of-school English language learning tended to obtain lower grades in the test than students who did engage in out-of-class learning. These studies convey a consistent message that the degree to which individual learners engage in out-of-class learning is associated with their language learning outcomes. 
Current research literature shows that the out-of-class learning activities language learners engage in vary in nature. Benson (2011) conceptualized four dimensions to differentiate the various out-of-class learning activities: location, formality, pedagogy and locus of control. Location refers to the physical, social and pedagogical relationships between the learners and the people and resources in the learning environments (i.e., classroom-based or non-classroom-based). Formality refers to the degree to which the learning experience is educationally structured and organized or qualification-granting (i.e., formal, non-formal or informal). Pedagogy refers to the extent to which educational processes such as the sequencing of contents and explicit explanations and assessments are involved (i.e., self-instruction pedagogy or naturalistic pedagogy). Locus of control refers to the degree to which learners perceive their learning to be controlled by themselves or by other people or instructional materials (i.e., other-directed or self-directed).

A number of studies have examined how students utilize out-of-class learning opportunities, the “pedagogical” dimension in Benson’s (2011) framework. For instance, Doyle and Parrish (2012) found that the Japanese university students in their study mainly engaged in "traditional ways of using English outside of class" in their spare time, such as studying for tests, and only a few engaged in more "creative and resourceful" activities, such as talking to themselves in English, singing karaoke in English, and so on (p. 200). Bailly (2010) classified the out-of-class learning activities of teenager English language learners in France into two types: "serious" activities involving conventional learning techniques learned at school, such as doing grammar and vocabulary exercises, taking notes and so on, and "lighter" activities that connected to their lives, such as chatting and watching television. She found that the “seriously" motivated learners, such as "the diploma seekers”, tended to engage in serious activities more frequently, and that the less seriously motivated learners, such 
as "the socialisers" and "the identity seekers", were more likely to engage in lighter activities.

Researchers have also examined the locus of control of out-of-class learning. For instance, Lai and Gu (2011) surveyed Hong Kong undergraduate foreign language learners on the nature of their self-directed use of technology for learning outside the school. Students' survey responses showed that, although to varying degrees, they mostly used technologies to manage goal commitment, resource and attitudinal needs (e.g., to use technologies to persevere in achieving language learning goals, expand their language learning resources, to sustain interest in learning the language, etc.), and were generally less likely to use technologies to manage their metacognitive and social needs (e.g., to use technologies to monitor their learning progress, to connect with other learners, etc.). Furthermore, learners who had greater self-regulated language learning dispositions, a stronger belief in seeking language use opportunities beyond the classroom and greater confidence in their proficiency level were more likely to use technological resources to support language learning beyond the classroom.

Researchers have further found that different types of activities are associated with different learning outcomes. Sundqvist (2011) found that, among the out-of-class activities that Swedish English language learners engaged in, activities that required the learners "to rely heavily on their language skills", such as surfing the internet, reading books and reading newspapers/magazines, were better predictors of learners' oral proficiency level and vocabulary size than activities such as listening to music, watching TV and watching films (p. 114). Palviainen (2012) examined Finnish university students majoring in either English or Swedish on their out-of-class English or Swedish language learning experiences. They found that the learners of English were active in utilizing much broader sources and venues, both receptive and 
productive, for learning outside the classroom, whereas the learners of Swedish used a much narrower range of activities and sources of learning. The two groups of learners demonstrated different levels of confidence in their language skills, with the former expressing more confidence in their language abilities than the latter. Fagerlund (2012) compared six Finnish learners’ out-of-class English language learning activities with their out-of-class Swedish language learning activities. She found that the learners engaged in both receptive and productive activities in English, and perceived their out-of-class English language learning as positive and empowering. In contrast, they engaged mostly in receptive activities in Swedish and expressed doubts about whether they had gained anything from their out-of-class Swedish language learning experiences. Thus, the same group of language learners engaged in different types of activities when learning English and Swedish, and perceived the values of out-of-class learning differently.

Therefore, different activities affect learners' perceptions of their out-of-class learning experiences and the learning outcomes. When examining the nature and impact of out-of-class learning, we need to consider not only the quantity of activities, "but also the influence of the quality of learning opportunities” (Bäumer et al., 2011, p. 92). As Blyth and LaCroix-Dallugh (2011) pointed out, if we are to engage learners systematically in creating effective learning through a combination of formal and informal learning, "it is essential not only to expand time for each but also ensure each is done well” (p. 19). Thus, understanding what quality out-of-class learning experience entails is vital. Unfortunately, despite the accumulated accounts of learners' out-of-class learning experiences, the current field is limited in its understanding of the characteristics of quality out-of-class learning (Arbelaiz \& Gorospe, 2009; Barron, 2010; Bailly, 2010). This study aimed to advance our understanding by examining the characteristics of out-of-class English learning 
activities that are associated with good learning outcomes.

An insightful perspective from which to examine the characteristics of quality out-of-class learning experiences is that of learning ecology. Brown (2000) compares the learning environment to an ecology comprising various dynamic and interdependent elements, and these various formal, non-formal and informal learning elements interact with each other to form an individual's learning ecology (Barron, 2006; Colley, Hodkinson \& Malcolm, 2003). A healthy ecology relies on various constituents having unique strengths that work together in a complementary manner (Nardi \& O’Day, 1999; Siemens, 2003), and this diversity is crucial in sustaining the adaptability and well-being of a learning ecology (Brown, 2000). Thus, this study used the diversity of the holistic learning ecology as a principle to examine the quality of out-of-class learning activities. Following this theoretical perspective, quality learning activities are the ones that form networks of activities to help achieve balance in learning. In language learning, this diversity manifests itself in a balanced focus on form and meaning (Ellis, 2005) and the fulfillment of the learner's various needs in language learning (Bäumer et al. 2011; Blyth \& LaCroix-Dalluhn, 2011; Lai \& Gu, 2011). This study aimed to determine whether the diversity of out-of-class learning activities is an indicator of quality out-of-class learning experiences. Specifically, this study was intended to answer two research questions:

RQ1: Is the diversity of out-of-class learning experiences associated with English language learning outcomes?

RQ2: What factors affect the construction of diversified out-of-class learning experiences?

\section{METHOD}

\section{Participants}

Participants were 82 EFL learners in their second year of junior high school in a 
big city in mainland China. Their average age was 14, and they had been studying English for an average of five years at the time of the study. Their English language proficiency ranged from A2 to B1 on the CEFR scale. Fifty-four percent of the participants were male and forty-six percent were female. The participants were volunteers from two classes taught by the same English teacher at the school, the third author of the study. All the students and their parents from the two classes were informed of the study and invited to participate in the study on a voluntary basis by the first author through class announcements and letters to the parents. The second and third author helped to distribute the letters to the parents on behalf of the first author. Eighty-two out of the eighty-six students from the two classes volunteered to participate in the study. The participants lived in an urban area in mainland China near to Hong Kong, providing relatively easy access to English learning resources including materials and native speakers of English, and they had easy access to computers and the Internet.

\section{Settings}

The school was a foreign language middle school and placed a relatively greater emphasis on the English language curriculum than the average middle schools in China. The overall number of English instructional hours at the school was similar to that at average middle schools. The school offered a more rigorous English language curriculum that used two textbooks: the textbook prescribed by the education bureau and a more sophisticated and authentic English textbook, "Longman Welcome to English” (Don Dallas, 2004). The school had also incorporated some innovative components into its English language curriculum. For instance, it offered English language movie dubbing classes once a month and hosted annual English language culture festivals that featured activities such as English language karaoke competitions. Parents who sent their children to the school were normally from the 
middle class with good socioeconomic standing, and they generally valued English more than parents who sent their children to average schools. Despite the various measures the school took to highlight its emphasis on English, the school was a government school and subject to the same jurisdiction of the district education bureau and centralized exams as is the case with average schools.

\section{Procedures}

A paper questionnaire in the participants' native language was administered in class. The questionnaire elicited the quantity, types and nature of the participants' out-of-class English language learning. Open-ended questions were asked to elicit the amount of time the participants spent on studying English outside the school and on using technological resources to support their English language learning other than finishing the homework assigned by the teacher in the past six months. To examine the diversity of their out-of-class learning activities, the participants were also asked to write down the English language activities they had engaged in outside their English classroom, excluding teacher-assigned homework, in the previous six months. Moreover, since technological resources and venues constitute a major source of out-of-class language learning in the digital era (Lai \& Gu, 2011; Benson, 2007; Sundqvist, 2011), the way in which the participants used technological resources and tools to support their out-of-class learning would also shed light on the diversity of the participants' out-of-school learning. Thus, twenty-three Likert scale questions (1= strongly disagree; $6=$ strongly agree) were used to examine whether and how participants used technological resources and tools to meet various metacognitive, goal commitment, attitudinal, resource and social needs in self-directed language learning outside the language classroom (see Appendix 1 for the survey items). These items were adapted from the questionnaire in Lai \& Gu's (2011) study. Participants were informed that technology referred to both information and communication 
technologies, such as the Internet, online games, audio/video, chatting, blogs, etc., and digital technologies, such as MP3, mobile devices, multimedia software, TV, and so forth.

To determine the learning outcomes, both the participants' attitudes towards English and their English grades were examined. Single-item questions were used to elicit the participants' confidence in learning English (1=not confident at all; $6=$ very confident) and how much they enjoyed learning English (1= not enjoyable at all; 6=very enjoyable). The questionnaire was administered close to the end of the semester (See the Appendix showing how the data elicited mapped onto the variables investigated in this study). Participants' end-of-semester English grades were also collected. The grades were based on the participants' performance in the final exam, which was the centralized exam from the district education bureau and assessed students’ vocabulary and grammar knowledge, and listening, reading and writing skills. It was an in-class timed exam. The exam items were mainly multiple-choice questions and cloze passages. The writing assessment was graded by individual teachers according to the grading rubrics from the district education bureau.

Follow-up focus group interviews were conducted with nineteen participants. Participants who reported different patterns of cognitive and non-cognitive outcomes and different frequencies of out-of-class learning (either a lot or very little) in their questionnaire responses were invited to the interviews. The purpose of the interviews was to tap into how the participants selected, perceived and used different out-of-class activities so as to obtain deeper insights into the nature of their out-of-class learning, and to understand the factors that affected the quality of their out-of-class learning experiences. The interviews were conducted in groups of three to four participants who reported similar out-of-class learning profiles so that they would feel more at ease and be more open and in-depth when discussing their learning behaviors 
(Lederman, 1990). The focus group interviews elicited the participants' views on their in-class and out-of-class learning experiences, their approaches to English language learning, their perceptions and use of different out-of-class activities, where the idea of engaging in these activities had come from, the challenges they encountered in constructing out-of-class learning experiences and the support they needed.

\section{Analytical Frame work}

Given that diversity is essential to a healthy learning ecology, quality out-of-class learning in this particular learning situation was provisionally defined as learning that was diversified. Namely, quality learning experiences involved activities that complemented in-class learning experiences and struck a balance between focus on form and focus on meaning in the holistic learning experience. Also, quality learning experiences realized the unique strengths of informal learning venues to meet the variety of socio-psychological needs in language learning.

Following this analytical framework, the study used three indicators of the nature of out-of-class learning. Indicator one was the degree to which the out-of-class learning was varied (i.e. variety of activity types). It was measured by counting the number of out-of-class learning activities (e.g., attend ing tutorial classes, listening to songs in English, reading novels in English, etc.) that the participants had written down in their response to the open-ended question in the questionnaire. Thus, variety was defined on the basis of the participants' perceptions. For instance, reading newspapers and reading novels were counted as two activities because, although both activities were reading activities, the fact that the participants had noted them down as two entries in their responses suggested that these activities were perceived as different activities and might have served different functions for the participants.

Indicator two was the number of meaning-focused activities the participants engaged in outside their English language classrooms. Their English lessons focused 
heavily on formal linguistic features, as revealed from conversations with the instructor and confirmed in the students' interview data. Therefore, the number of different types of meaning-focused activities that each participant engaged in outside the classroom could indicate how well a balance had been struck between focus on form and focus on meaning in the learners' overall experiences (i.e., variety of meaning-focused activity types). Thus, we categorized learner-reported out-of-class learning activities into form-focused activities and meaning-focused activities. Form-focused activities focused more on the linguistic system and the formal elements of the language. Examples of form-focused activities were: doing grammar exercises, reviewing the textbooks, taking remedial tutorial classes, and so on. Meaning-focused activities were more authentic activities, which gave the participants naturalistic language exposure with the overriding focus on meaning and communication. Examples of meaning-focused activities were: reading novels in English, watching English language movies and playing computer games in English, online chatting, and so on (Doughty \& Williams, 1999). The number of different types of meaning-focused activities that each participant reported engaging in was counted.

Indicator three focused specifically on the participants' use of technology for English language learning outside the classroom. It measured the extent to which technology-enhanced out-of-class learning helped to meet the participants' various socio-psychological needs in language learning (i.e., diversity of purpose of technology use). Five different dimensions of technology use in self-regulating out-of-class learning experience (Lai \& Gu, 2011) were examined: managing goal commitment, metacognition needs, resource needs, social connection needs and attitudinal needs. Participants' ratings on the items across these five different dimensions were averaged. The number of dimensions that had an average rating of 4 and above (slightly agree) was totaled and used as the third indicator of the diversity 
of out-of-class experience (e.g., if an individual had three dimensions with an average over 4 , then he/she would be given a score of 3 for this measure).

Three measurements of learning outcomes were used: end-of-semester exam grade, confidence in learning English, and enjoyment in learning English. Three measurements of learning outcomes were included because the impact of out-of-class learning far exceeds conventional cognitive outcomes, and confidence and enjoyment are possible affective outcomes from such learning experience (Author, under review; Bell et al., 2009; Blyth \& LaCroix-Dalluhn, 2011).

The relationship between the three quality indicators and the three learning outcome measurements was examined to determine how diversity worked as a general principle in order to evaluate the quality of out-of-class learning. The relationship between the amount of out-of-class learning - the hours spent on out-of-class English language learning each day_ and the three learning outcomes was also examined to compare the relative association of the quantity and the quality of out-of-class learning experiences with learning outcomes. Furthermore, stepwise multiple regression analyses were conducted to examine how well the quantity and quality indicators predicted the three learning outcomes.

Thematic analysis was used to analyze the interview data with both deductive and inductive phases. The data were first analyzed deductively into predetermined themes to understand the construction of out-of-class learning as suggested by the existing literature. The themes included:1) types of activities outside the English class, 2) how each activity was used, 3) perceptions of the functions of different activities for learning, 4) influential forces in the construction of out-of-class learning, 5) challenges in constructing out-of-class learning, and 6) support needed. Interview data were then analyzed inductively to generate concrete categorizations under each predetermined theme. Transcripts were read line by line and meaningful segments of 
text that struck the researchers as interesting or important to the study were coded. In- vivo codes were used in the initial coding. Then similar codes were aggregated into analytic categories, which were informed by both the theoretical framework and the data base. The initial codings of the analytic categories were then compared across interviewees to find repeating ideas and contrasting instances (Charmaz, 1990). For example, under the predetermined theme, "influential forces in the construction of out-of-class learning", there were in-vivo codes like, "My dad studies Grammar books together with me every Saturday and Sunday”, "My parents bought an electronic learning machine for me to learn English", "My parents do not encourage me to use technology”, and so on. These in-vivo codes were aggregated into analytic categories such as “parents shape learning approaches”, "parents gate-keep learners’ activity selection”, "parents select/arrange activities for the learners”, and so on.

\section{RESULTS}

In this section, we first present an overview of the students' in-class and out-of-class English language learning experiences to set the background. We then present the quantitative and qualitative data showing the relationship between the diversity of out-of-class learning experiences and learning outcomes to answer the first research question. We end this section with the qualitative data on factors that affected the diversity of out-of-class learning experiences to answer the second research question.

\section{The Nature of In-Class and Out-Of-Class English language Learning}

Interviews with the participants indicated that their in-class English language learning was heavily form-focused. When asked what their in-class learning was like, some participants reported it as being teacher-centered. For instance, one participant reported, “In class, usually it's the teacher who did the talk. We just listened and then did the worksheets." Another said, "most of the times, the class was us doing the 
worksheets and the teacher explaining the texts in the textbook.” Other participants described their English classes as knowledge driven: "I mainly learned grammar from the teacher," "the teacher mainly taught the grammar and then gave us dictations etc.," and "the English class was all about listening to the teacher lecturing and absorbing the knowledge." "Boring” was the word participants constantly used when talking about their English classes. They wished that the teacher would not always ask them to recite the texts and that she would give them more opportunities to use the language. Quite a few participants expressed their wish that the English classes would allow for more student involvement: "I wish the English class could be more active. Not just in the form of teacher lecturing and us listening.”

As for their out-of-class learning experiences, the questionnaire responses showed that the participants reported spending an average of 1.18 hours each day engaging in self-initiated English language learning outside their English classes. There was great variation in the amount of time they spent on out-of-class English language learning ( $\mathrm{SD}=0.99)$. Concerning their use of technology to support out-of-class English language learning, the participants were found to spend an average of 4.52 hours each week using technology to support their English language learning outside school. An average of 2.31 hours out of the 4.52 hours were spent on using technology to finish the teacher-assigned homework, and 2.21 hours were spent on using technology to explore extra English language learning opportunities and resources.

Similar to the findings in previous studies of out-of-class English language learning across different countries (Hyland, 2004), the participants in the present study were found to engage in a variety of out-of-class learning activities, with watching English language movies and listening to songs in English being the most common activities. Taking English tutorial classes was another oft-reported 
out-of-class learning activity (See Figure 1).

[Insert Figure 1]

Most of the activities were of a receptive nature, exposing the participants to various audiovisual and written inputs. Only a few participants mentioned that they engaged in a limited number of language production activities, such as chatting with classmates or family members, email exchanges with native speakers and keeping English diaries. Furthermore, the participants also reported that they frequently engaged in quite a few form-focused activities: doing all sorts of drills and practices and quizzes, studying grammar books, memorizing vocabulary lists, and reading aloud after English language recordings to practice their pronunciation. The participants also mentioned that they recited passages from Longman New Concept English (Alexander, 2010), a popular English language textbook used in tutorial classes and for self-study purposes, as part of their out-of-class learning experience. Thus, the participants demonstrated a heavy reliance on self-study activities and learning materials with “a high level of formality and instructional content” (Benson, 2011, p. 12).

\section{[Insert Table 1]}

\section{Relationship between the Diversity of Out-of-Class Learning and Learning}

\section{Outcomes}

Table 1 gives an overview of the diversity of the participants' out-of-class learning experiences and their English language learning outcomes. It shows that the participants reported adopting an average of 3 different types of activities or venues for out-of-class English language learning, of which 2 were meaning-focused activities. There was great variation in the variety of activities the participants engaged in, ranging from as many as 8 different types of learning activities and 6 meaning-focused activities to as few as 1 learning activity and 0 meaning-focused 
activity. An examination of the diversity of participants' technology use outside English classes in meeting their various needs in learning English revealed that the participants gave positive ratings for the use of technologies to enrich and expand their English language learning resources, and help them to commit to their learning goals, regulate their emotions and interest in learning, and plan and monitor their own learning process, with means ranging from 4.19 to 4.57 (See Table 1). However, they gave somewhat negative ratings, and with the greatest variation, for the use of technology to meet their social connection needs in language learning ( $\mathrm{M}=3.99$, $\mathrm{SD}=1.23)$. This finding is consistent with the out-of-class technology use for language learning found among university students in HK (Lai \& Gu, 2011). Table 1 also shows great variations in the participants' English grades, confidence in learning English and enjoyment in learning English.

The correlation analyses showed that the quantity of out-of-class learning did not correlate significantly with learners' confidence in learning English, their enjoyment in learning English and their English grades. In contrast, the diversity of out-of-class learning experiences correlated significantly with the three outcome indicators (Table 2). Specifically, the more types of out-of-class learning activities the participants engaged in, the more the participants enjoyed learning English ( $r=0.45$, $p$ $<.01)$, the greater confidence they had in learning English well $(r=0.42, p<.01)$ and the better their English grades were $(r=0.25, \mathrm{p}<.05)$. The same pattern held true for the variety of meaning-focused activities: The more the participants engaged in a variety of meaning-focused activities outside their English classroom, the more they enjoyed learning English $(r=0.47, \mathrm{p}<.01)$, the greater confidence they had in learning English well ( $r=0.41, \mathrm{p}<.01)$ and the better the English grades they obtained $(\mathrm{r}=0.30)$. Furthermore, participants’ diversified use of technological resources and tools correlated significantly with their attitudinal learning outcomes and, although not 
significantly, with their English grades. The more learning needs that the participants used technology to support outside their English classes, the more they enjoyed learning English $(r=0.46, \mathrm{p}<.01)$, the greater confidence they had in learning English well ( $r=0.36, p<.01)$, and the better their English grades were $(r=0.22)$. Thus, the findings suggest that the nature, rather than the quantity, of out-of-class learning was significantly associated with English language learning outcomes (Bäumer et al. 2011; Blyth \& LaCroix-Dalluhn, 2011). Solely engaging in out-of-class activities that echo their form-focused instruction in class, such as doing grammar and vocabulary drills and studying grammar books, is likely to be associated with poor learning outcomes and reduced interest in learning, regardless of how many hours learners spend on such activities. This is because a sole focus on form is far from being an optimal language learning experience (Ellis, 2005; Benson, 2011).

[Insert Table 2]

Table 2 also shows that the correlations of the three indicators of the diversity of out-of-school learning experiences with confidence and enjoyment in learning English were greater than with English grades. This finding makes sense since it has been argued that out-of-class learning is mostly associated with the development of non-cognitive capacities, such as habits of mind, identities, interest, confidence and so on (Bell et al., 2008, Blyth \& LaCroix-Dalluhn, 2011).

Regression analyses were also conducted to estimate the influence of the indicators of the diversity of out-of-class learning on the various learning outcomes. The regression analyses showed that the variety of out-of-class meaning-focused activities and the diversity of participants' technology use in meeting their needs in learning English were significant predictors of the learning outcomes. Variety of meaning-focused activities alone explained $10 \%$ of the variation in the participants' English grades. Variety of meaning-focused activities and diversity of technology use 
together explained 20\% of the variation in participants' confidence in learning English and 30\% of the variation in participants' enjoyment in learning English learning (see Table 3). Thus, the variety of out-of-class meaning-focused activities was consistently a significant predictor of all the three learning outcome indicators. This finding suggests that when the in-class instruction is characterized by a heavy focus on language forms, the degree to which the out-of-class learning activities focus on meaning and complement in-class learning experience is indeed an important characteristic of quality out-of-class learning experiences.

\section{[Insert Table 3]}

Diversity of technology use was also a significant predictor of confidence and enjoyment in learning English. The more learning needs the participants tried to meet with the help of technology, the greater their confidence and enjoyment in learning English was. This suggests that learners' engagement in a variety of out-of-class technology-enhanced activities that meet the multitude of psychological and socio-affective needs associated with language learning does contribute significantly to the quality of out-of-class learning experiences.

The importance of having out-of-class learning experiences that complement in-class learning experience was also a major theme that emerged from the interview data. The interviewees with lower English grades and who rated themselves as having less confidence and enjoyment in learning English overwhelmingly reported having engaged in activities that reviewed what was learned in class, such as reviewing textbooks, studying grammar books and doing grammar exercises, and listening to textbook tapes. In contrast, the interviewees who had better learning outcomes reported having engaged in far fewer such activities in the past six months and felt that they "had had enough of them at school". Furthermore, the interviews showed that interviewees with poorer learning outcomes tended to use apparent 
meaning-focused activities in a form-focused way. For instance, some of them reported using English language movies and songs primarily to learn grammar, or chatting/emailing with relative abroad "to increase vocabulary" or "to practice grammar”.

Consistent with the regression analysis findings, the interview data suggested that what might have mattered more to the quality of the out-of-learning experiences was not whether or not the participants participated in a variety of English language learning activities outside their classroom, but whether or not the activities complemented the class activities by being more meaning-focused and served a wide range of socio-psychological needs in language learning. The following two contrastive cases attested to the importance of engaging in out-of-class learning experiences that complement in-class learning. The two participants, De and Yi, reported different levels of confidence in and enjoyment of learning English, despite both reporting in a variety of out-of-class learning activities during the semester. De rated her confidence and enjoyment quite highly (5 and 6 respectively) in the questionnaire and received a grade of 88 in the end-of-semester exam, whereas $\mathrm{Yi}$ gave himself a rating of 2 and 4 for confidence and enjoyment respectively and received a grade of 80 in the exam. De’s learning activities included communicating with classmates, consulting family members, listening to English language songs, watching English language movies, and communicating with others via microblog. Yi’s English language learning activities included surfing the web for English language materials, watching TV programs, listening to songs, reading newspapers and magazines, and communicating with classmates. Despite the equally varied learning activities they engaged in, their use of the resources varied. In Yi's case, the varied learning venues were used and perceived in a very limited sense. He chose to watch instructional TV programs about the English language. He read the bilingual 
newspaper distributed by the school and used it as formal learning material: "I read it once it's distributed and sometimes I even review it”. He would communicate with classmates who were good at English to elicit corrective feedback on pronunciation: 'I speak with them. When I pronounce some words wrongly, I’ll check with them to get the words corrected.” Thus, his out-of-class learning experiences, although seemingly varied, were quite homogeneous and characterized by strong “self-instruction” pedagogy (Benson, 2011, p. 11), and basically reinforced the form-focused instruction in his English class. His primary focus was on language knowledge, and he was not aware of the other psycho-socio needs that out-of-class learning experiences could potentially serve (Blyth \& LaCroix-Dalluhn, 2011; Wang, 2012; Author, under review). In contrast, for De, the different learning activities served diversified and heterogonous functions. She communicated with classmates to get help on some remaining grammar questions and to exchange English learning strategies. She watched English language movies and listened to English language songs to learn some specialized vocabulary in English. She microblogged in order to practice using English to communicate smoothly. Thus, although De also engaged in some form-focused activities, her out-of-class learning served a wider array of functions with some activities compensating for the lack of meaning-focused instruction in her English class and helping meet her other needs in learning English in addition to acquiring language knowledge.

\section{Factors that Affect the Diversity of Out-of-Class Learning}

The interview data also revealed various factors that affected the diversity of the out-of-class learning that these middle school students engaged in. Parents were a major influence on the participants' construction and perceptions of their out-of-class learning experiences. Most interviewees mentioned that their parents were major influences shaping their out-of-class English language learning, and that their parents 
played a very active role in their learning experience. Parents were reported to influence the participants’ out-of-class learning through sharing English language learning strategies, thus shaping the participants’ learning approaches. One interviewee reported, "My dad studies Grammar books together with me every Saturday and Sunday.” Another interviewee said that when he chatted with his cousin online, his parents often sat next to him to monitor his learning experience: "When he says something I don't understand, he'll teach me, and then my parents will require me to write it down and rote learn it." His parents also required him to rote learn good paragraphs when he was reading English language books. Parents' emphasis on grammar might, to some extent, have explained why quite a few participants focused primarily on grammar and vocabulary even when engaging in "meaning-focused" activities. Parents also influenced the participants' out-of-class learning experiences by acting as gatekeepers, encouraging or discouraging the types of activities their children engaged in. Quite a few of the participants mentioned that their parents did not allow or encourage them to use computers as a means of learning English, or that their parents controlled the time they could stay on the computer. One interviewee's parents even had expectations concerning the types of computer-assisted activities that their child should or should not engage in:

S: My parents do not encourage me to use technology

R: Why?

S: They feel that technology will make us lazy. It makes it too easy to obtain knowledge. Although it's efficient, it is not good for memorization

R: How about chatting with others online?

S: Online chatting is good. My parents support it. But they don’t encourage searching for information online, including using online dictionaries...

R: They don't encourage you to use a dictionary? 


\section{S: They recommend using a paper dictionary.}

Another interviewee's mother encouraged her to learn English through computer programming since, as she put it, “its language was very standardized. My mom told me that grammar is important.” Parents also influenced the participants’ out-of-class learning through providing learning resources and venues, such as enrolling their children in tutorial classes or buying grammar quizzes or books for their children. As one interviewee said, "the tutorial classes have taken up the time I used to have to go to the bookstores to read English language books and novels and to watch English movies.” However, for another interviewee, the suggestions from his parents actually helped to broaden his learning experience:

My parents don’t know English, but when they happened to see the neighbor's child using online dictionaries, they encouraged me to try. I started to use online dictionaries for learning English and have been continuing to do so till now. I have also expanded my use of the computer to read online English books and watch online videos since then.

The participants also reported that their teacher affected their out-of-learning experiences by influencing the way they selected and used the activities. For one interviewee, the idea of studying the supplementary CD to review the vocabulary in the textbook and listen to the texts outside English class came from the encouragement of his teacher. Another interviewee's English teacher in primary school had made him aware of the potentials of technology-enhanced English language learning:

My English teacher at the primary school always told me to surf English websites and listen to English songs when I had time. I did that, and then I found what we learned at school was much less than what we could get from technological venues. 
Thus, teachers' encouragement helped broaden the range of students' out-of-class learning experiences. At the same time, however, teacher guidance on how to use different out-of-class learning activities might also have shaped their approaches to learning from out-of-class activities. As one interviewee said, "my teacher encouraged us to listen to tapes and songs to understand how the words are pronounced.” Teachers also affected the participants' learning behaviors through influencing their parents. Teachers' suggestions on what resources to use for out-of-class learning influenced the resources that parents provided for their children: "my teacher recommended some drill and practice books, and my parents bought them and encouraged me to do them at home.” One interviewee also pointed out that his teacher's acknowledgement of a certain learning venue/activity would directly determine whether his parents would encourage him to use that learning venue/activity or not.

Various other factors also influenced the participants' out-of-class learning experience. One important factor was locus of control, that is, their perceptions of who was responsible for controlling the learning process. Locus of control has been found to play a determinant role in the success of self-instructed language learning (Bown, 2006). In this study, we found that some of the participants believed that their learning was controlled by their parents, teachers and school. Quite a few students were not satisfied with their learning environments, but they felt that it was the school's responsibility to make the instructional environment more "authentic", “activity-centered”, “communication-oriented.” One interviewee commented:

The school needs to do more to improve the learning environments because no matter how many resources we find outside the school, the time outside the school is limited after all. We have more opportunities for English learning inside the school.

Some participants also felt the locus of control partly lay with their parents: "parents 
should give us the general plan and we need to rely on ourselves to get it done.” In addition to the influence of locus of control, participants also reported that other factors constrained their out-of-school experience, including poor reading and listening comprehension skills, an espoused approach to language learning that stressed “memorization and practice”, and weak self-regulation skills (Lai \& Gu, 2011). As one student put it: "I find it hard to persevere, especially with online learning activities”

\section{DISCUSSION}

This study found that engaging in out-of-class learning experiences that complemented participants' in-class learning experience significantly predicted both cognitive and non-cognitive language learning outcomes. Given that the instructional context in this study was very much form-focused, out-of-class experiences that involved different types of meaning-focused activities and activities that helped to meet participants’ many psychological and socio-affective needs in language learning were associated with good learning outcomes. This suggests that the degree of diversity in the overall language learning ecology could be an appropriate criterion to evaluate the quality of out-of-class learning experiences. This is just a small step towards understanding the complex issue of the quality of out-of-class learning. Bäumer et al. (2011) reviewed educational research to determine the core factors of learning opportunities and identified four basic factors that determine quality learning experiences: 1 ) structure (how the educational processes take place in the learning environment), 2) support (emotional, social and pedagogical support available in the learning environment), 3) challenge (the appropriateness of the difficulty level of the activities in leading learners to their “zone of proximal development”), and 4) orientation (the existence of shared values and norms and favorable attitudes).

Bäumer et al. (2011) argued that these four core factors, although originally generated 
from the classroom instruction context, are valid in evaluating the characteristics of other learning environments and experiences. The present study only focused on the diversity aspect of the structure component of learning ecology, and future studies are needed to examine the nature of out-of-class learning experiences by focusing on other aspects of the core factors of learning opportunities.

This study found that most of the middle school EFL learners in the study did take the initiative to engage in various out-of-class learning activities, but the nature of their out-of-class learning varied. Being able to exert agency to construct one’s out-of-class learning experiences does not necessarily mean that these experiences are beneficial (Doyle \& Parrish, 2012; Pearson, 2004; Bailly, 2011). Thus, it is important to develop and enhance EFL learners' ability to construct quality language learning experiences (Bailly, 2011). Quite a number of students in this study mainly resorted to learning materials with a high level of formality and relied heavily on instructional materials in out-of-class settings, and by so doing moved the locus of control away from themselves (Benson, 2011). This finding suggests that we need to help learners build the confidence to take control over their learning and develop the ability to learn through naturalistic learning. Teachers can help build up the mentality and confidence of learners by encouraging them and providing spaces or structure for more learner control in their classroom practices. They could also help by including more materials from popular culture and authentic materials from the web and teaching learners the strategies to use such materials so that they could be more confident and capable of learning from these naturalistic materials (Wang, 2012; Thorne \& Reinhardt, 2010). Through enhancing their abilities to engage with naturalistic materials and environments, we may be able to encourage students to move the locus of control back to themselves and create more diversified learning experiences outside their language classrooms (Benson, 2011). It is equally important to raise students' 
awareness of their various needs in effective language learning and how various out-of-class learning activities could be utilized to help meet these needs (Author, under review; Wang, 2012). By guiding students to redefine the roles of various out-of-class learning activities, we could help them to go beyond the dominant “self-instruction” pedagogy they apply to most learning activities (Benson, 2011) and start to view and use different activities in different ways and for different purposes so as to obtain a holistic language learning experience from their out-of-class efforts.

This study also identified parents and teachers as playing major roles in shaping the diversity of the learners' out-of-class learning experiences. This finding concurs with previous research findings on middle school student homework behavior, where students reported that one major purpose for doing homework was to get approval from parents and teachers, and that family help and teacher feedback were factors influencing students' homework interests and management (Xu, 2007, 2010). This finding suggests that for students of this age group, student training may need to be supported via parent training and teacher professional development in respect to the construction of quality out-of-class learning experiences. It is important to develop parents' understanding of what successful language learning involves and what the optimal language learning conditions are. It is equally important to raise their awareness of the importance of including a wide range of out-of-class learning activities that serve diversified functions in language learning. Teachers also played an important role in shaping students' out-of-class learning directly and indirectly through shaping the parents' understanding. Thus, language teacher professional development needs not only to focus on effective practices in instructional contexts, but also to include an important component on how to bridge formal and informal learning contexts to help students construct a holistic learning experience. Teachers need to understand what they can do in class to help students construct quality 
out-of-class learning experiences and to use the resources/venues appropriately to contribute to quality out-of-class learning experiences.

\section{CONCLUSION}

This study analyzed the out-of-class learning experiences constructed by middle school EFL students in order to understand how to evaluate the quality of such experiences. Adopting an ecology metaphor and using the diversity of the ecology as the general principle, the study defined quality out-of-class learning experiences as learning experiences that contribute to and maintain diversity in the overall language learning experience. It found that when class instruction was dominated by form-focused instruction, the variety of meaning-focused out-of-class learning activities and the diversity of technology use in serving different language learning needs significantly predicated English class grades, confidence in learning English, and enjoyment in learning English. It also found that the middle school EFL students' out-of-class learning experiences varied greatly, and that parents and teachers were the two major influences on the nature of the out-of-class learning experiences that the participants constructed. The study suggests that in instructional contexts where the instruction is heavily form-focused, such as in China, helping students to engage in more meaning-focused activities and use activities in ways that help to fulfill their diverse needs in language learning might make a difference to students' overall learning experience and learning outcomes. Therefore, it is important to help language learners to understand the importance of diversifying their learning experiences by selecting and using out-of-class learning activities/venues in ways that compensate for what is lacking in their in-class learning. Furthermore, we also need to help parents and teachers to understand the importance of diversified learning experiences so that they can give appropriate advice, guidance and support to learners in constructing beneficial out-of-class learning experiences. 
This study was based on a group of participants who were attending a school that placed greater emphasis on learning English than the average middle school in China, and who were from middle class families with expectations with respect to their children's English language proficiency. The particularities of the personal and institutional contexts of the participants may limit the representativeness of the findings concerning the frequency of their out-of-class English learning and the type of out-of-class English learning activities that they engaged in. However, these participants' grammar-focused in-class learning experience is quite typical of the English language instructional situation in China (Pan \& Block, 2011; Song, 2013), and thus, the findings concerning the positive association between the diversity of out-of-class learning experiences and learning outcomes may very well be meaningful in different contexts in China.

This study has several limitations. First of all, the study was based on the experiences of a particular age group in a particular sociocultural setting (i.e. middle school EFL learners in China). Some of the research findings might therefore be due to the particularity of the participants. For instance, the strong parental influence on students' construction of out-of-class learning experience might have been due to the Chinese cultural background and the particular age group. Further studies are needed to explore the same issue in different cultural backgrounds and with different age groups in order to reach a fuller understanding of the phenomenon.

Second, this study was situated in a particular EFL context, where the in-class instruction was heavily form-focused. The finding concerning the importance of out-of-class learning that includes a variety of meaning-focused activities that strike a balance between focus on meaning and focus on form in language learning might be due to the particular context. It would be interesting to find out whether the same quality criterion is significant in instructional contexts where a balance between 
meaning and form has already been achieved and in learning situations where no formal instruction is involved. Future studies may delve deeper into the interaction between in-class learning and out-of-class learning, for example, by comparing what quality out-of-class learning entails in different language classrooms with different pedago gical arrangements of focus-on-meaning, focus-on- form and focus-on- forms. It would also be interesting to see whether the diversity of technology use in serving different language learning functions is a significant quality indicator of out-of-school learning experiences in a second language learning context where target language learning resources and opportunities abound.

Third, the study only revealed the existence of linear associations between diversity of out-of-class learning and some cognitive and non-cognitive learning outcomes, and was not able to establish any causality claims on the relationship. The observed association of the diversity of out-of-class learning experience with learning outcomes could just as well be interpreted as learners with stronger English language skills and confidence opting for a variety of meaning-focused activities because they were successful and capable of doing so, and learners with weaker English language skills and confidence relying on form-focused activities because that was what they could do. Thus, longitudinal research or research with pre- and post- measures is needed to investigate the causal relationships between the variables.

Fourth, the findings were limited by the fact that the non-cognitive outcomes, confidence and enjoyment, were elicited through single- item measures. The end-of-semester grades also came from the centralized exam that did not contain oral components, which might have explained the observed weaker association between the diversity of out-of-class learning and cognitive outcome. Future studies may need to use fine-grained measures of these outcomes to better capture the relationships.

Finally, given the critical role that parents played in influencing the nature of 
students' out-of-class learning, an in-depth understanding of parents' perceptions is important. Such understandings could inform the design of parent education programs that support parents to give quality guidance and support to their children. In this study, parents' perceptions were revealed through the students' accounts, which is quite limited. Future studies may tap directly into parents’ perception of quality out-of-class English learning.

With out-of-class learning receiving more and more attention in the education arena, it is of the utmost importance to understand the characteristics of quality out-of-class learning experiences before we can move on to promote such experiences to create a holistic learning experience that goes beyond the language classroom. This study is a small step towards understanding the quality of out-of-class learning experiences. More research is needed to explore further different characteristics of quality out-of-class learning experiences and in different learning situations, and how we can help students to develop the relevant knowledge and skills.

\section{ACKNOWLEDGEMENTS}

This article is based on a project (GRF7461/10H) funded by the Research Grants Council of the Government of the Hong Kong SAR. The authors would like to thank the anonymous reviewers and the editor of the journal TESOL Quarterly for their constructive and valuable feedback on earlier versions of this article.

\section{THE AUTHORS}

Chun Lai is an assistant professor at the University of Hong Kong. Her research 
interests include self-directed language learning beyond the classroom and technology

enhanced language learning. Her recent research focuses on understanding

self-directed language learning beyond the classroom and identifying factors to

support self-directed use of technology for language learning.

Weimin Zhu is a senior English lecture at Nan Shan Foreign Language School, Shen

Zhen, China.

Gang Gong is an English lecture at Nan Shan Foreign Language School, Shen Zhen,

China.

\section{Reference}

Alexander, L. G (2010). Longman new concept English. Beijing: Foreign Language Teaching and Research Press.

Arbelaiz, A. M., \& Gorospe, J. M. C. (2009). Can the grammar of schooling be changed? Computers \& Education, 53, 51-56.

doi:10.1016/j.compedu.2008.12.016

Bailly, S. (2011). Teenagers learning language out of school: What, why and how do they learn? How can school help them? In P. Benson \& H. Reinders (Eds.), Beyond the language classroom (pp.119-131). New York: Palgrave Macmillan. 
Barron. B. (2006). Interest and self-sustained learning as catalysts of development: A learning ecologies perspective. Human Development, 49, 193-224. doi:10.1159/000094368

Barron, B. (2010). Conceptualizing and tracing learning pathways over time and setting. National Society for the Study of Education, 109, 113-127.

Bäumer, T., Preis, N., Roßbach, H., Stecher, L., \& Klieme, E. (2011). Education processes in life-course-specific learning environments. Z Erziehungswiss, 14, 87-101. doi: 10.1007/s11618-011-0183-6

Bell, P., Lewenstein, B., Shouse, A. W., \& Feder, M. A. (2009). Learning science in informal environments: People, places and pursuits. National Research Council. Washington, DC: The National Academies Press.

Benson, P. (2011). Language learning and teaching beyond the classroom: An introduction to the field. In P. Benson \& H. Reinders (Eds). Beyond the language classroom (pp.7-16). New York: Palgrave Macmillan.

Benson, P. (2007). Autonomy in language teaching and learning. Language Teaching, 40, 21-40. doi: 10.1013/s0261444806003958

Benson, P. \& Reinders, H. (2011). Beyond the language classroom: The theory and practice of informal language learning and teaching. Basingstoke: Palgrave Macmillan. 
Benson, P., Chik, A. \& Lim, H. Y. (2003). Becoming autonomous in an Asian context: Autonomy as a sociocultural process. In D. Palfreyman \& R. C. Smith (Eds.), Learner autonomy across cultures: Language education perspectives (pp. 23-40). Basingstoke: Palgrave Macmillan.

Blyth, D. A., \& LaCroix-Dalluhn, L. (2011). Expanded learning time and opportunities: Key principles, driving perspectives, and major challenges. New Directions for Youth Development, 131, 15-27. doi: 10.1002/yd.405

Borrero, N., \& Yeh. C. J. (2010). Ecological English language learning among ethnic minority youth. Educational Researchers, 39, 571-581. doi:10.3102/0013189X10389810

Bown, J. (2006). Locus of learning and affective strategy use: Two factors affecting success in self-instructed language learning. Foreign Language Annals, 39, 640-659. doi: 10.1111/j.1944-9720.2006.tb02281.x

Brown, J. S. (2000). Growing up digital: How the web changes work and education and the ways people learn. Change, 11-20. doi:10.1080/00091380009601719

Butler, Y. G (2011). The implementation of communicative and task-based language teaching in the Asia-Pacific region. Annual Review of Applied Linguistics, 31, 36-57. doi: 10.107/S0267190511000122

Charmaz, K. (1990). 'Discovering’ chronic illness: Using grounded theory. Social 
Science \& Medicine, 30, 1161-1172. doi: 10.1016/0277-9536(90)90256-R

Colley, H., Hodkinson, P., \& Malcolm, J. (2003). Informality and formality in learning: A report for the learning and skills research centre. London: Learning and Skills Research Center.

Don Dallas, L. P. (2004). Longman welcome to English. Hong Kong: Longman Publishing.

Doughty, C. \& Williams, J. (1999). Focus on form in classroom second language acquisition. Cambridge: Cambridge University Press.

Doyle, H., \& Parrish, M. (2012). Investigating students’ ways to learn English outside of class: A researchers’ narrative. Studies in Self-Access Learning Journal, 3, 196-203.

Ellis, R. (2005). Instructed second language acquisition: A literature review. Wellington: Ministry of Education New Zealand.

Fagerlund, T. (2011). Learning and using English and Swedish beyond the classroom: activity systems of six upper secondary school students. (Unpublished master's thesis). University of Jyväskylä, Finland.

Gao, X. S. (2010). Strategic language learning: The roles of agency and context. Bristol: Multilingual Matters.

Hall, R. (2009). Towards a fusion of formal and informal learning environments: The 
impact of the read/write web. Electronic Journal of e-Learning, 7, 29-40.

Hyland, F. (2004). Learning autonomously: Contextualizing out-of-class English language learning. Language Awareness, 13, 180-202. doi: 10.2307/3586981

Inozu, J., Sahinkarakas, S., \& Yumru, H. (2010). The nature of language learning experiences beyond the classroom and its learning outcomes. US-China Foreign Language, 8, 14-21.

Lai, C. \& Gu, M. Y. (2011). Self-regulated out-of-class language learning with technology. Computer Assisted Language Learning, 24, 317-335. doi:10.1080/09588221.2011.568417

Lai, C. (2013). A framework for developing self-directed technology use for language learning. Language Learning \& Technology, 17, 100-122.

Larsson, B. (2012). English out-of-school activities: A way of integrating outwards? (Unpublished Master Thesis). University of Gävle, Gävle.

Leander, K. M., Phillips, N. C., \& Taylor, K. H. (2010). The changing social spaces of learning: Mapping new mobilities. Review of Research in Education, 34, 329-394. doi: 10.3102/0091732X09358129

Lederman, L. C. (1990). Assessing educational effectiveness: The focus group interview as a technique for data collection. Communication Education, 38, 117-127. doi: 10.1080/03634529009378794 
Menezes, V. (2011). Affordances for language learning beyond the classroom. In P.

Benson \& H. Reinders (Eds.), Beyond the language classroom (pp.59-71).

New York: Palgrave Macmillan.

Nardi, B.A., \& O'Day, V.L. (1999). Information ecologies: Using technology with heart. Cambridge, MA: MIT Press.

National Research Council (2009). Learning science in informal environments: people, places and pursuits. Washington, DC: The National Academies Press.

Nunan, D. (1991). Language Teaching Methodology. London: Prentice Hall.

Palviainen, Å. (2012). Lärande som diskursnexus: finska studenters uppfattningar om skoltid, fritid och universitetsstudier som lärokontexter för svenska. Nordisk tidskrift for andrespråksforskning, Nr 1-2012, 7-36.

Pan, L. \& Block, D. (2011). English as a 'global language’ in China: An investigation into learners’ and teachers’ language beliefs. System, 39, 391-402. doi:10.1016/j.system.2011.07.011

Pearson, N. (2004). The idiosyncrasies of out-of-class language learning: A study of mainland Chinese students studying English at tertiary level in New Zealand. In Proceedings of the Independent Learning Conference 2003. Retrieved from http://www.independentlearning.org/uploads/100836/ila03_pearson.pdf

Richards, J. C. (2009). The changing face of TESOL. Plenary Speech at TESOL 
Convention and Exhibit. Retrieved from

http://www.professorjackrichards.com/wp-content/uploads/changing-face-of-T

ESOL.pdf

Sefton-Green. J. (2006). Literature review in informal learning with technology

outside school. Bristol, UK: Futurelab.

Siemens, G. (2003). Learning ecology, communities and networks: Extending the classroom. Retrieved from

http://www.elearnspace.org/Articles/learning_communities.htm

Song, M. (2013). Participant perceptions about speaking and listening in modern foreign language classes in China and England, and their relationship to classroom practices. (Unpublished doctoral dissertation). University of Warwick, Warwick.

Stickler, U., \& Emke, M. (2011). Tandem learning in virtual spaces: Supporting non-formal and informal learning in adults. In P. Benson \& H. Reinders (Eds.), Beyond the language classroom (pp.146-160). New York: Palgrave Macmillan.

Sundqvist, P. (2011). A possible path to progress: Out-of-school English language learners in Sweden. In P. Benson \& H. Reinders (Eds.), Beyond the language classroom (pp.106-118). New York: Palgrave Macmillan. 
Thorne, S. L., \& Reinhardt, J. (2008). “Bridging activities,” new media literacies, and advanced foreign language proficiency. CALICO Journal, 25, 558-572. doi:10.11139/cj.25.3.558-572

Wang, D. P. (2012). Self-directed English language learning through watching English television drama in China. Changing English: studies in Cultures and Education, 19, 339-348. doi: 10.1080/1358684X.2012.704584

Wilhelm, K. H. \& Pei, B. C. (2008). University teachers and students' perceptions of ELT methodologies and their effectiveness. GEMA Online Journal of Language Studies, 8, 79-102.

Xu, J. Z. (2007). Middle-school homework management: More than just gender and family involvement. Educational Psychology, 27, 173-189. doi:10.1080/01443410601066669

Xu, J. Z. (2010). Homework purposes reported by secondary school students: A multilevel analysis. Journal of Educational Research, 103, 171-182. doi:10.1080/00220670903382939 
Appendix: Data collection mapping onto the variables under investigation

\begin{tabular}{|c|c|c|c|c|}
\hline & & \multicolumn{3}{|c|}{ Survey Item/Grades } \\
\hline \multirow[t]{2}{*}{$\begin{array}{l}\text { Quantity of } \\
\text { out-of-class } \\
\text { learning }\end{array}$} & $\begin{array}{l}\text { Amount of time spent in } \\
\text { out-of-class English } \\
\text { learning }\end{array}$ & \multicolumn{3}{|c|}{$\begin{array}{l}\text { On the average, how many hours each day did you spend in learning English outside the } \\
\text { classroom in the past six months? ___ hours }\end{array}$} \\
\hline & $\begin{array}{l}\text { Amount of time spent on } \\
\text { using technology to support } \\
\text { out-of-class learning }\end{array}$ & \multicolumn{3}{|c|}{$\begin{array}{l}\text { On the average, how many hours each week did you spend in using technology to support English } \\
\text { learning outside the classroom in the past six months? ___ hours }\end{array}$} \\
\hline \multirow{6}{*}{$\begin{array}{l}\text { Nature of } \\
\text { out-of-class } \\
\text { English learning }\end{array}$} & $\begin{array}{l}\text { Activities engaged outside } \\
\text { school }\end{array}$ & \multicolumn{3}{|c|}{ What do you usually do outside the school to help with English learning? } \\
\hline & \multirow[t]{5}{*}{$\begin{array}{l}\text { Use of technology to meet } \\
\text { language learning needs }\end{array}$} & \multirow[t]{5}{*}{$\begin{array}{l}\text { regulate } \\
\text { attitudinal needs }\end{array}$} & $\begin{array}{l}\text { When having negative feelings towards English learning, I use } \\
\text { technology to maintain interest in learning English }\end{array}$ & \multirow[t]{5}{*}{$\alpha=0.82$} \\
\hline & & & $\begin{array}{l}\text { I actively use technology to avoid negative feelings towards } \\
\text { English learning }\end{array}$ & \\
\hline & & & $\begin{array}{l}\text { I use technology to make English learning more attractive to } \\
\text { me }\end{array}$ & \\
\hline & & & $\begin{array}{l}\text { I boost my confidence in English learning through chatting } \\
\text { online or reading English materials online }\end{array}$ & \\
\hline & & & $\begin{array}{l}\text { Techno logy effectively maintains my interest and enthusiasm } \\
\text { in learning English }\end{array}$ & \\
\hline
\end{tabular}




\begin{tabular}{|c|c|c|c|c|}
\hline & & & $\begin{array}{l}\text { When I feel I need more learning resources in English, I use } \\
\text { technology to expand my learning resources }\end{array}$ & \\
\hline & & & $\begin{array}{l}\text { I use technology to expand my English learning experience } \\
\text { beyond the language classroom }\end{array}$ & \\
\hline & & & $\begin{array}{l}\text { I use technology to create and increase opportunities to learn } \\
\text { and use English }\end{array}$ & \\
\hline & & & $\begin{array}{l}\text { I use technology to make it possible to study English at any } \\
\text { time and any place }\end{array}$ & \\
\hline & & & I use technology to seek help on English from different venues & \\
\hline & & regulate social & I use technology to communicate with English speakers & $\alpha=0.91$ \\
\hline & & connection needs & $\begin{array}{l}\text { I use technology to communicate with English learners all over } \\
\text { the world }\end{array}$ & \\
\hline & & & $\begin{array}{l}\text { I use technology to seek encouragement and support from } \\
\text { English learners all over the world }\end{array}$ & \\
\hline $\begin{array}{l}\text { Learning } \\
\text { outcomes }\end{array}$ & Non-cognitive outcomes & confidence & $\begin{array}{l}\text { Are you confident in learning English well? (Rate your level of } \\
\text { a scale of } 1-6,1=\text { no confidence at all, } 6=\text { very confident) }\end{array}$ & onfidence on \\
\hline & & enjoyment & $\begin{array}{l}\text { Do you enjoy learning English? (Rate your level of enjoyment o } \\
1-6,1=\text { not enjoy at all, } 6=\text { enjoy learning very much) }\end{array}$ & a scale of \\
\hline & Cognitive outcomes & End-of-semester $\mathrm{E}$ & glish grades collected from the instructor & \\
\hline
\end{tabular}

